\title{
Macroeconomic Determinants of Non-Performing Loans in Bangladesh: An ARDL Approach
}

\author{
Md. Ziaul Hasan \\ MPhil Researcher \\ Bangladesh University of Professionals \\ Dhaka-1216, Bangladesh \\ E-mail:md.ziaulhasan@ucb.com.bd \\ DOI: $10.31364 / S C I R J / v 7 . i 7.2019 . P 0719675$ \\ http://dx.doi.org/10.31364/SCIRJ/v7.i7.2019.P0719675
}

\begin{abstract}
This paper empirically studies the macroeconomic factors determining the non-performing loans (NPLs) of the banking institutions in Bangladesh. Using a set of time series data from 2000 to 2017, Auto-Regressive Distributed Lag (ARDL) method was employed to discover the significant relationships between the variables. The study concludes that macroeconomic variables namely Gross Domestic Product Growth Rate (GDPGR) and Inflation Rate (INFR) have no significant impact on the level of NPLs in Bangladesh. The result of this research is useful to assist banks and the regulators for policy formulation and also help researchers for their study relating to NPL.
\end{abstract}

Index Terms - Non-performing Loans, macroeconomic determinants, Bangladesh, GDP growth, inflation rate, ARDL

\section{INTRODUCTION}

Banks play the foremost role in the developing economy like Bangladesh for mobilizing savings from the surplus economic unit and providing capital to the investors. Banks' performance has significant impacts on allocation of capital and economic growth. Thus, performance of banks is very much important not only for that specific bank, but also for the entire economy. (Achou and Tenguh 2008). Providing loans and advances to the customers is the banks' prime revenue generating activity. Generally, the loans and advances are the major portion of the banks' asset and their main source of income (Achou and Tenguh 2008).

The term "NPL" is used interchangeably with "bad loans" as described by Basu (2003). Berger and De Young (1997) indicate NPLs as "problem loans". Fofack (2005) termed it as "impaired loans". In the banking industry of Bangladesh the term "Classified Loans" is also used to indicate NPL. Hou (2006) and Bloem and Gorter (2002) mentioned in their studies that, globally acceptable definition of NPL is not yet formulated. Banking systems of different countries define loan classification system with different scopes and contents. Issa (2009) shows that there are variations in definition of NPL among the banking systems of different countries according to their laws and regulations. Bloem and Gorter (2002) show that, banks used both quantitative and qualitative criteria to classify the loans. Usually, number of days is used as a quantitative criterion of loan classification and all the information about the future of the borrower and loans are used as qualitative criteria for classification of loans.
Non-performing Loans (NPLs) are those loans of the banks' from which they are no longer able to receive interest or overdue principal payments. So, NPLs decrease banks' profitability. Increase in NPL also decreases the loanable fund in the financial market. Banks' may have to face capital erosion due to higher level of NPLs. NPLs can affect the balance sheet of banks and due to interconnectedness of banking sector with the overall financial system and the economy, there may have ripple effects throughout the financial system thereby contributing to financial instability. Thus, exploring the affecting factors of NPLs is a matter of essential importance for the regulatory authorities, banks and governments concerned on financial stability. This study aims to determine the impact of macroeconomic variables on NPLs in Bangladesh.

\section{A. Impact of NPLs on Banking Growth}

A bank having a high level of NPLs has to incur carrying costs on non-income generating assets that affect not only the profitability but also the capital adequacy of a bank, and in consequence, the bank faces difficulties in augmenting capital resources. A study from IMF (2015) found that countries where the banks have high levels of NPLs credit growth remains slow. Firms those are more dependent on bank finance are likely to be affected more than other firms from the reduced lending capacity of banks. It was also mentioned from IMF (2015) that banks that have high levels of NPLs on their balance sheets, they also have a lower ability for lending to the real economy. This happens through 3 major channels:

Lower profitability: A high level of NPL implies less net operating income for a bank and also reduce profits significantly due to the greater effort that required in order to manage and monitor the large stock of NPLs.

Higher capital requirements: An increased level of NPL increases the risk weights and as a result higher capital requirements will be needed.

Higher funding cost: Other Banks and investors have less willingness to lend or lend with higher rate of interest to the banks having higher level of NPLs.

\section{B. Impact of NPLs on Economy}

As per the ECB annual review high level of 'Non Performing Exposure's or NPEs (i.e. NPLs) create a severe macro prudential problem. First, a large stock of NPLs indicates that households and firms are excessively indebted and impaired, 
which may decrease consumption and investment, and consequently delay economic recovery. Second, scarce resources in the banking sector, capital, funding, as well as operational capacity, are absorbed by bad assets (NPLs) and cannot be reinvested in new viable investment projects. This, in turn, may elongate the period of subdued economic activity, further aggravating the NPL problem for the banking sector and the economy as a whole'.

\section{NPLs in Bangladesh}

In the context of Bangladesh, well-functioning of the banking sector and subsequent economic development has been significantly constrained by the continuing crisis of the accumulation of NPLs. To ensure transparency and quality of the banks' loan portfolios, determine the actual volume of quality assets and strengthen credit discipline, Bangladesh Bank, in 1989, adopted prudential norms under Financial Sector Reform Program (FSRP) for Loan Classification and Provisioning covering rules, the suspension of interest due, and the making of provisions against potential loan loss.

According to IMF, A loan is non-performing when payments of interest and principal are past due by 90 days or more, or at least 90 days of interest payments have been capitalized, refinanced or delayed by agreement, or payments are less than 90 days overdue, but there are other good reasons to doubt that payments will be made in full. By bank regulatory definition non-performing loans consist of:

i. Loans that are past due by 90 days or more and still accruing interest, and

ii. Loans which have been placed on nonaccrual (i.e., loans for which interest is no longer accrued and posted to the income statement).

Loan may also be non-performing if it is used in a different way than that for which it has been taken. As per Section 5 (cc) of Bank Company Act 1991, 'defaulting debtor' means any person or institution served with advance, loan granted in favour of him or an institution involving interest or any portion thereof, or any interest which has been overdue for six months in accordance with the definition of Bangladesh Bank. According to Bangladesh Bank "classified loan" is the term used for any loan that a bank examiner has deemed to be in danger of defaulting. The borrower does not necessarily need to miss payments order for a bank to label the account in this manner. The ratio of gross non-performing loan to total outstanding is called the NPL rate.

\section{Present Scenario}

In the banking industry of Bangladesh, the average ratio of gross non-performing loan to total outstanding is $14.6 \%$ for the last eighteen years but A steady average NPL trend of $9.2 \%$ has been maintaining during the last five years. Average GDP growth rate is 5.95 and Inflation rate is 6.43 for the last eighteen years.

The overall trend of NPL, GDP growth rate and Inflation rate in Bangladesh from the beginning of this century is shown in the following figure.

Figure - 1: NPL Rate, GDP Growth Rate and Inflation Rate trend in Bangladesh

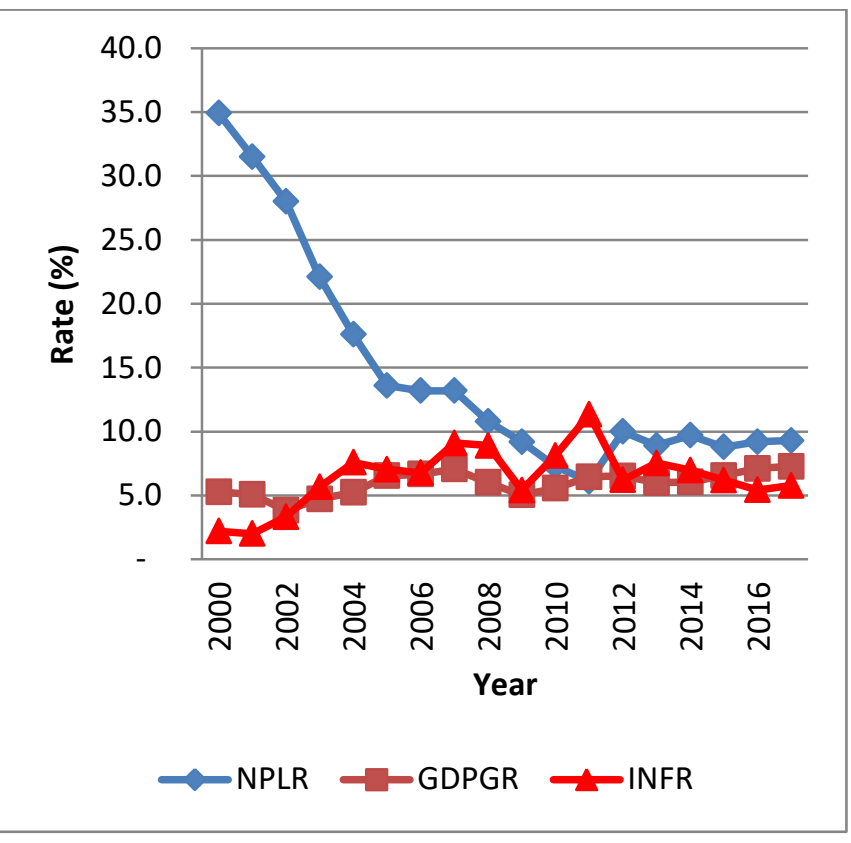

Source: Bangladesh Bank and World Bank Group

\section{LITERATURE REVIEW}

There are many studies conducted all over the world on the problem of NPL in the banking sector.

Makri et al. (2014) show strong correlations between various bank-specific and macroeconomic factors by using aggregate data for the period 2000-2008 on a panel of 14 countries. Ekanayake et al. (2015) show that, macroeconomic variables like inflation and GDP growth rate have significant inverse relationship with NPLs.

Lis et al. (2000) econometrically identified various bankspecific and macroeconomic factors of NPL by using panel data of Spanish commercial banks for the period 1985-1997. They found that GDP growth rate has a negative effect on NPL.

Fofack 2005 and Nkusu 2011 show that Inflation adversely affects borrowers' capacity for servicing his debt. Inflation may have positive or negative impact on NPL, which is explained in the literature that, higher inflation reduces the real value of loan outstanding which makes the borrower more capable for servicing the debt. Inflation also reduces the real income of the borrower which may weaken the borrower's repayment capacity. Sinkey and Greenwalt (1991) also found that depressed regional economic conditions explain the lossrate of the commercial banks, by using large US commercial banks' data. Salas and Saurina (2002) found out the relationship between real growth in GDP and NPLs by studying Spanish banks' data.

Keeton and Morris (1987) studied on US commercial banks using simple linear regressions and found that large portion of loan losses recorded by the banks are associated to adverse local economic conditions. Bercoff et al (2002) examined the fragility of the Argentinean Banking system over the 19931996 periods; they argue that NPLs are affected by both bank specific factors and macroeconomic factors. Rajan and Dhal (2003) found that macroeconomic factors have significant impact on NPLs. They used a panel regression analysis for their study. Statistical analysis by Waweruand Kalini (2009) on the commercial banks in Kenya also found that high 
macroeconomic condition is one of the factors of NPLs. Islam and Nishiyama (2016) present the empirical results on how bank specific, industry specific and macroeconomics specific factors affect the bank non-performing loans in south Asian countries by using GMM estimator. Waqas, Fatima, Khan and Arif M. (2017) show that both macroeconomic and bank specific variables are significantly related to NPLs. Roy, Dey and Bhowmik (2017) show that two macro-economic variables GDP growth and inflation are negatively related to NPL in Bangladesh. Zainol, Nor, Ibrahim, \& Daud (2018) found significant long term impact of GDP growth rate and Inflation rate on NPL by using ARDL method.

\section{METHODOLOGY}

\section{A. Data Collection}

GDP growth rate, inflation rate of Bangladesh and NPL data of all the 56 scheduled banks in Bangladesh is collected from secondary sources for the period from 2000 to 2017. NPL data is collected from Annual Reports of Bangladesh Bank of different years. GDP growth rate and inflation rate data is collected from World Bank group database.

\section{B. Data Analysis}

"STATA 15" statistical software package is used for both descriptive and quantitative analysis of the collected data. The present scenario of NPL in Bangladesh and the economic indicators are presented through the descriptive analysis. In quantitative analysis, Augmented Dickey-fuller Unit Root Test is done to check the stationarity. Auto-Regressive Distributed Lag (ARDL) Cointegration test is done to identify the existence of cointegration and long-run equilibrium relationship among the variables.

\section{Model:}

The linear model may be expressed as follows-

$N P L R_{t}=f\left(G D P G R_{t}, I N F R_{t}\right)$ Equation -1

where:

$$
\begin{array}{ll}
\text { NPLR } & =\text { Non-Performing Loan to Total Loans } \\
\text { GDPGR } & =\text { Gross Domestic Products Growth Rate } \\
\text { INFR } & =\text { Inflation Rate }
\end{array}
$$

\section{Autoregressive Distributed Lag (ARDL) Cointegration}

ARDL cointegration technique is preferable when dealing with variables that are integrated of different order, I(0), I(1) or combination of the both and, robust when there is a single long run relationship between the underlying variables in a small sample size. The long run relationship of the underlying variables is detected through the F-statistic (Wald test). In this approach, long run relationship of the series is said to be established when the F-statistic exceeds the critical value band. (Pesaran, M. H., and Y. Shin 1998)

In order to perform ARDL bound $\mathrm{F}$ test for examining the existence of long-run relationship, an ARDL equation called as Unrestricted Error Correction Model (UECM) is constructed for all proposed model from research objectives

The transformation of all models is listed below:

$$
\begin{gathered}
N P L_{t}=\beta_{0}+\sum_{n=1}^{p} \beta_{1} N P L_{t-p}+\sum_{n=1}^{p} \beta_{2} G P D G R_{t-p} \\
+\sum_{n=1}^{p} \beta_{3} I N F R_{t-p} \\
+\theta_{0} N P L_{t-1}+\theta_{1} G P D G R_{t-1}+\theta_{2} I N F R_{t-1}+\varepsilon_{t}
\end{gathered}
$$

Equation - 2

The lag length represented by $\mathrm{p}$ has to be determined to implement the bound test approach in equation (2). At the next stage, F statistics should be implemented on the first lags of dependent and independent variables in inquiring the presence of a cointegration. The long run relationship hypotheses necessary for this test are given below:

$$
\mathrm{H}_{0}: \theta_{0}=\theta_{1}=\theta_{2}=0 \text { (there is no long-run relationship) and }
$$$$
\mathrm{H}_{1}: \theta_{0} \neq \theta_{1} \neq \theta_{2} \neq 0 \text { (there is a long-run relationship exists) }
$$

which suggest the existence of cointegration among the variables. The presence of cointegration was based on Fstatistic value. This F-statistic value is then compared with the critical value introduced by Pesaran et. al. (2001). If the estimated F-statistic is greater than the upper bound value of the table, we can reject the null hypothesis and accept the alternative hypothesis that cointegration exist. On the other hand, if F-statistic is lower than the lower bound, the null hypotheses cannot be rejected and thus the cointegration in the proposed model does not exist.

\section{ANALYSIS, RESULTS AND FINDINGS}

\section{A. Descriptive Statistics:}

The mean, standard deviation, minimum and maximum value of the variables for the period from 2000 to 2017 is presented in Descriptive statistics.

Table - 1: Descriptive Statistics

\begin{tabular}{|c|c|c|c|c|}
\hline Variable & Mean & $\begin{array}{c}\text { Standard } \\
\text { Deviation }\end{array}$ & Minimum & Maximum \\
\hline NPLR & 14.6 & 8.7 & 6.1 & 34.9 \\
\hline GDPGR & 5.9 & 0.9 & 3.8 & 7.3 \\
\hline INFR & 6.4 & 2.3 & 2.0 & 11.3 \\
\hline
\end{tabular}

Source: Compiled by the author based on collected data

\section{B. Augmented Dickey Fuller Unit Root Test:}

Augmented Dickey Fuller Unit Root Test has been done to identify that weather all the variables are stationary or not. All the variables under this study must ne stationary to perform regression analysis. The result of the test is as follows -

Table - 2: Augmented Dickey Fuller Unit Root Test - 1

\begin{tabular}{|c|c|c|c|}
\hline Variable & T Statistic & $\begin{array}{c}\text { Significance } \\
\text { level }\end{array}$ & I (d) \\
\hline NPLR & -4.283 & $1 \%$ & I (0) \\
\hline GDPGR & -3.262 & $5 \%$ & I (1) \\
\hline INFR & -4.817 & $1 \%$ & I (1) \\
\hline
\end{tabular}

Source: Compiled by the author based on collected data 
Variable NPLR is found stationary at level $\mathrm{I}(0)$ at significance level of $1 \%$, GDPGR found stationary at level I(1) at significance level $5 \%$ and INFR is found stationary at level I(1) at significance level $1 \%$.

\section{ARDL Cointegration Test}

The results in Table- 3 indicate that cointegration exists between the variables. In this analysis, maximum lag at 3 with an optimum order of 1, 0, 1 for Akaike Information Criteria (AIC) is used. According to Narayan (2004), F-statistics need to be compared with the critical value provided. The results of cointegration showed in Table-3 that F-statistic (6.536) obtained from the optimum lag is greater than critical value of upper bound at $1 \%$ significant level, which indicates that there is existence of cointegration between NPL and macroeconomic variables i.e GDP growth rate and inflation rate. The results shown in Table- 4 and Table- 5 that there is no statistically significant long run or short run relationship between NPL rate and macroeconomic variables i.e GDP growth rate and inflation rate.

Table-3: ARDL Tests for Co-integration for Model of NPLs

\begin{tabular}{|c|c|c|c|}
\hline F-Statistic & $\begin{array}{c}\text { Maximum } \\
\text { Lag }\end{array}$ & AIC & Result \\
\hline $\mathbf{6 . 5 3 6}$ & $\mathbf{3}$ & $\mathbf{1 , 0 , 1}$ & $\begin{array}{c}\text { Cointegration } \\
\text { Exist }\end{array}$ \\
\hline \multicolumn{3}{|c|}{ Critical Value Bounds } \\
\hline Significance & Lower Limit & Upper Limit \\
\hline $10 \%$ & 3.17 & 4.14 \\
$5 \%$ & 3.79 & 4.85 \\
$2.5 \%$ & 4.41 & 5.52 \\
$1 \%$ & 5.15 & 6.36 \\
\hline
\end{tabular}

Table 4: Results of the Estimation of Long Run Coefficients

\begin{tabular}{|c|c|c|c|c|}
\hline Variable & Coefficient & $\begin{array}{c}\text { Std. } \\
\text { Error }\end{array}$ & $\begin{array}{c}\text { t- } \\
\text { Statistic }\end{array}$ & P \\
\hline GDPGR & 3.248515 & 3.930504 & 0.83 & 0.425 \\
\hline INFR & -1.71799 & 1.204886 & -1.43 & 0.179 \\
\hline
\end{tabular}

Table 5: Results for Short Run Error Correction Model of NPLs

\begin{tabular}{|c|c|c|c|c|}
\hline Variable & Coefficient & $\begin{array}{c}\text { Std. } \\
\text { Error }\end{array}$ & $\begin{array}{c}\text { t- } \\
\text { Statistic }\end{array}$ & P \\
\hline GDPGR & -.2167032 & 0.240067 & -0.90 & 0.384 \\
\hline INFR & -.1825992 & 4.889055 & -0.04 & 0.971 \\
\hline
\end{tabular}

\section{CONCLUSION AND RECOMMENDATION}

Non-performing loans are considered as one of the most hazardous factors for any Banking industry. The banks having high level of NPLs requires to keep higher level of provision for loan loss that decreases the bank's revenue and reduces the funds for new lending. This study attempts to investigate the impact of macroeconomic determinants on NPLs in commercial banks in Bangladesh using secondary data. Contrary to most of the international evidence, findings of this study do not support the view that the level of NPL is significantly affected by macroeconomic factors specifically GDP growth rate and Inflation rate. This study considered only the macroeconomic variables to explain NPL. Other bank-specific factors such as Credit growth, Capital adequacy, profitability may have larger impact on NPL in Bangladesh; or willful or habitual default culture may be the most significant cause of NPL in Bangladesh. Further study is required to investigate the other determinants. Whatever the factors, it is required to manage and resolve the NPL problems for a stable financial and banking sector; proper execution of effective NPL management and resolution techniques may be useful to combat NPL issues. More sophisticated and proactive policies are required to be made for the reduction of NPL in the banking system. A separate agency may be created under Bangladesh Bank to carry out loan supervision activities more meticulously. Separate Loan Recovery Tribunal may be established to ensure faster loan recovery under a stronger legal framework. Asset Management Companies should be established for dealing with NPLs. Collateral plays an important role in resolving NPL resolution, but at present the execution process of loan recovery through encashment of collateral is very lengthy and difficult. Difficulties in valuing collateral is also exists in Bangladesh and proper regulation in this regard is essential. A central database for collateral may be established to share the information among the banks. Execution of other out of court settlement methods like Asset securitization, Alternative Dispute Resolution, Banking Ombudsman etc. will help resolution of existing NPLs and prevent loans to become NPL in Bangladesh.

\section{REFERENCES}

[1] Achou, FT \& Tenguh, CN 2008, "Bank performance and credit risk management", MA Degree Project in Finance, Skovode Univercity

[2] Anastasiou, D., Louri, H., and Tsionas, M. 2016, "Determinants of non-performing loans: Evidence for euro area countries", Finance Research Letters, Vol. 18, pp. 116-119.

[3] Anastasiou, D., Louri, H., and Tsionas, M., 2016, "NonPerforming Loans in the Euro Area: Are Core-Periphery Banking Markets Fragmented?", Bank of Greece Working Paper Series, Vol. No. 219.

[4] Aremu, M. A., Mejabi 2013, Determinants of banks profitability in developing economy: 4(9) pp.155-181

[5] Ahmed, SZ 2006, "An investigation of the relationship between Non-performing Loans, Macroeconomic Factors, and Financial Factors in context of Private Commercial Banks in Bangladesh", Independent University, Bangladesh

[6] Baudino and Yun 2017, FSI Insights on policy implementation No 3, "Resolution of nonperforming loans - policy options"

[7] Bartel, J. and Huang, Y. 2000, "Dealing with the Bad Loans of the Chinese Banks", Columbia University Discussion Paper Series Discussion Paper No. 13

[8] Bangladesh Bank 2012: Master Circular on Loan Classification and Provisioning, issued by Banking Regulation \& Policy Department, BRPD Circular No. 14 date: September 23, 2012

[9] Basu, S 2003, "Why do Banks Fail?", International Review of Applied Economics, Vol. 17, pp. 231-248

[10] BCBS 2017, "Prudential treatment of problem assets definitions of non-performing exposures and forbearance"

[11] Berger, NA and DeYoung, R 1997, "Problem Loans and Cost Efficiency in Commercial Banks", Journal of Banking and Finance, Vol. XV, No.21, pp.849-870

[12] Booth, J. R. \& Booth, L.C. 2006, "Loan collateral decisions and corporate borrowing costs", Journal of Money, Credit and Banking, Vol. 38, pp. 67-90. 
[13] Bloem, AM \& Freeman, R 2005, "The Treatment of Nonperforming Loans in Macroeconomic Statistics", IMF Working Paper WP/01/209, International Monetary Fund.

[14] Bercoff, Jose J., Julian di, Giovanni \&FranqueGrimard. 2002. Argentinean Banks, Credit Growth and the Tequila Crisis: A Duration Analysis" (Unpublished)

[15] Campbell, A. 2007, "Bank insolvency and the problem of nonperforming loans", Journal of Banking Regulation, Vol. 9(1), pp. 25-45.

[16] Coco, G. 2000, "On the use of collateral", Journal of Economic Surveys, Vol. 14, pp. 191-214

[17] Espinoza, R., and Prasad A. 2010, "Nonperforming loans in the GCC banking system and their macroeconomic effects", IMF Working Paper, No. 10/224

[18] Ekanayake \& Azeez 2015, "Determinants of Non-Performing Loans in Licensed Commercial Banks: Evidence from Sri Lanka". Asian Economic and Financial Review, 2015, 5(6), pp 868-882

[19] Fofack, H 2005, "Nonperforming loans in Sub-Saharan Africa: Causal Analysis and Macroeconomic implication" World Bank Policy Research Working Paper 3769, //econ.worldbank.org

[20] Huang, Y., Bonin, J. 2001, "Dealing with the Bad Loans of the Chinese Banks"', Journal of Asian Economics, Vol.12, pp. 197214.

[21] Hu, J, Li, Y, and Chiu, Y 2004, "Ownership and nonperforming loans: Evidence from Taiwan's banks", The Developing Economics, Vol. 42, No.3, PP. 405-420

[22] Hou, Y 2006, "the non-performing loan problem: some bank level evidence", University of Birmingham Edgbaston, Birmingham

[23] IMF 2015, 'Euro area policies, selected issues: policy options for tackling non- performing loans in the euro area', IMF country report, Vol. 15/205.

[24] Issa, AG 2009, “Analysis of non-performing loans in the Libyan state-owned commercial banks: perception analysis of the reasons and potential methods for treatment", PHD thesis, Durham University

[25] Islam, S., Nishiyama, S. 2016. The determinants of nonperforming loans: dynamic panel evidence from South Asian countries. TERG Discussion Papers 353, Graduate School of Economics and Management, Tohoku University.

[26] Justice Mustafa Kamal 2004, "Judicial Settlement and Mediation in Bangladesh", HRPB

[27] Jovovic 2014, "Determinants of Non-Performing Loans: Econometric Evidence Based on 25 Countries. Master Thesis, City University London

[28] Keeton W. \& C. S. Morris .1987. Why Do Banks' Loan Losses Differ? Federal Reserve Bank of Kansas City, Economic Review, May, pp. 3-21.

[29] KPMG 2016, "European debt sales“, Loan portfolio advisory, Portfolio Solutions Group, KPMG International.

[30] Khan J, Khan I 2018, The Impact of Macroeconomic Variables on Stock Prices: A Case Study of Karachi Stock Exchange. Bus Eco J 9: 365

[31] Laeven, L., Majnoni G. 2003, "Loan Loss Provisioning and Economic Slowdowns: Too Much, Too Late?" Journal of Financial Intermediation, Vol. 12, No 2, pp.178-197.

[32] Lee, S. 2002, "Financial Restructuring in Korea and Japan: Resolution of Non-performing loans and reorganization of financial institutions", Journal of East Asian Studies, Vol. 2, pp. 143- 185.

[33] Leeth, J. D. \& Scott, J.A. 1989, "The incidence of secured debt: Evidence from the Small Business Community", Journal of Financial and Quantitative Analysis, Vol. 24, pp. 379-394
[34] Lehmann, A. 2017, "Carving out legacy assets: a successful tool for bank restructuring?", European Parliament's Committee on Economic and Monetary Affairs - Policy Contribution Issue, No. 9

[35] Louzis, D., Vouldis A., Metaxas, V. 2010, 'Macroeconomic and bank-specific determinants of non-performing loans in Greece: A comparative study of mortgage, business and consumer loan portfolios', Journal of Banking and Finance, Vol. 36(4), pp. $1012-1027$

[36] Masood, O., Bellalah, M., and Mansour, W. 2010, "NonPerforming Loans and Credit Managers' Role: A Comparative Approach from Pakistan and Turkey", International Journal of Business, Vol. 15(3), pp. 347-362.

[37] Matoušek R. and Bruno S. 2005, "Management of NonPerforming Loans in Eastern Europe", Journal of East-West Business, Vol. 11(1), pp. 141-166.

[38] Makri, Tsagkanos \& Bellas 2014, "Determinants of NonPerforming Loans: The case of Eurozone". Panoeconomicus, 61(2), pp 193-206

[39] New Zealand's Ombudsmen Act 1975

[40] Nkusu,W 2011, "Nonperforming Loans and Macrofinancial Vulnerabilities in Advanced Economies" International Monetary Fund, Vol.11, No.161

[41] Pesaran, M. H., and Y. Shin 1998, An autoregressive distributed-lag modelling approach to cointegration analysis. In Econometrics and Economic Theory in the 20th Century. The Ragnar Frisch Centennial Symposium, ed. S. Strom, chap. 11, 371-413. Cambridge: Cambridge University Press.

[42] PWC 2017, "Non-performing loans - Leveraging the right strategy to optimise your company's balance sheet"

[43] Rajan, Rajiv \&Sarat C. Dhal. 2003. Non-performing Loans and Terms of Credit of Public Sector Banks in India: An Empirical Assessment. Occasional Papers, 24:3, pp. 81-121, Reserve Bank of India.

[44] Roy, Dey and Bhowmik 2017, Non-performing loans in private commercial banks of Bangladesh: Macro-economic determinants and impacts, The Jahangirnagar Journal of Business Studies. 4(1): 47-57

[45] Sinhar, M. 2009, "Debt/Equity Swaps in Germany". International Corporate Rescue, Vol. 6

[46] Sinkey, Joseph. Fowler. \& Mary B. Greenwalt 1991, Loan-Loss Experience and Risk-Taking Behavior at Large Commercial Banks, Journal of Financial Services Research, 5: 43-59.

[47] Salas, Vincente \& Jesus Saurina 2002. Credit Risk in Two Institutional Regimes: Spanish Commercial and Savings Banks. Journal of Financial Services Research, 22:3, pp. 203-224.

[48] Toda, H. Y., Yamamoto, T. 1995, Statistical inference in vector auto-regressions with partially integrated processes. Journal of Econometrics 66: 225-250

[49] Turner, P. and Hawkins, J. 1999, 'Bank restructuring in practice: an overview', Policy Papers No. 6, Bank for International Settlements.

[50] USAID: Alternative dispute resolution practitioners guide, CMG's Advisory Group of ADR and conflict management experts includes Professors Frank Sander and David Smith of Harvard Law School; Robert Ricigliano, CMG Executive Director; Diana Chigas, CMG Regional Director; and Antonia Handler Chayes, CMG Senior Advisor

[51] Woo, D. 2000, "Two Approaches to Resolving Nonperforming Assets During Financial Crises'," International Monetary Fund Vol No. 33

[52] Waweru, N.M. \& Kalani, V. M. 2009, Commercial banking crises in Kenya: causes and remedies, African Journal of Accounting, Economic Economics, Finance and banking research, 4(4): 12-32 
[53] Waqas, Fatima, Khan and Arif M. 2017, Determinants of Nonperforming Loans: A Comparative Study of Pakistan, India, and Bangladesh, International Journal of Finance \& Banking Studies, 6(1):51-68

[54] www.bangladesh-bank.org/ November, 2018

[55] Xu, M. 2005, "Resolution of Non-Performing Loans in China", the Leonard N. Stern School of Business Glucksman Institute for Research in Securities Markets.

[56] Zainol, J. M., Nor, A. M., Ibrahim, S. N., \& Daud, S. 2018, Macroeconomics Determinants of Non-Performing Loans in Malaysia: An ARDL Approach. International Journal of
Academic Research in Business and Social Sciences, 8(10), 692-706.

[57] R. Nicole, "Title of paper with only first word capitalized," J. Name Stand. Abbrev., in press.

[58] Y. Yorozu, M. Hirano, K. Oka, and Y. Tagawa, "Electron spectroscopy studies on magneto-optical media and plastic substrate interface," IEEE Transl. J. Magn. Japan, vol. 2, pp. 740-741, August 1987 [Digests 9th Annual Conf. Magnetics Japan, p. 301, 1982].

[59] M. Young, The Technical Writer's Handbook. Mill Valley, CA: University

1989. 